\title{
Entrepreneur Skills on Business Performance of Small and Medium Enterprise
}

\author{
Ratih Hurriyati, Girang Razati, S.Sulastri, Novian Perdana Putra \\ Faculty of Economic and Business Education \\ Universitas Pendidikan Indonesia \\ ratih@upi.edu
}

\begin{abstract}
The low business performance of SMEs in Indonesia caused by weak managerial and technological, low market share, the shortage of capital, the narrow range of the market, cannot be ignored. One of the solutions to increase business performance in SMEs is improving their entrepreneur skill. The purpose of research is to know the description of the entrepreneurial skill in SMEs on Narogong, Bekasi, and know the describe of the business performance level of the SMEs in Narogong, Bekasi, and also entrepreneur skills influence on business performance at SME in Narogong, Bekasi. This type of research is descriptive and vericative, with explanatory survey on 30 owners of the SMEs. The result show that entrepreneurial skill has influenced business performance at $38,05 \%$ and $61,94 \%$ is influence by other factor. It means there is a strong significant influence of entrepreneurship skills against the business performance. To improve the business performance, the owners of SMEs should increase the entrepreneur skill in running their business to get satisfactory result.
\end{abstract}

Keywords- Business Performance, Entrepreneur Skill, Entrepreneuship, SMEs

\section{INTRODUCTION}

Small and medium size enterprise (SME) has a complementary role with major companies in the creation of employment opportunities as well as economic growth in a country. Small and medium enterprise in Indonesia had played an important role in several thing: 1) SMEs is a major player in economic activities in Indonesia; 2) SMEs has provide in employment opportunities; 3) Become important players for being a development of local economic and community development; 4) Become the creator of markets and innovation through dynamic versatile and sensitivibility as well as with dependencies with certain companies; 5) SMEs is contributed to increase of export and import non-oil and gas. These points can be supported with the ability of entrepreneurial skill in improving their business performance. Performance in a result who generates over specific job function or activity in period of time. Business performance is the result of work that can be accomplished by a person or group of people in an organization, according to the authority and responsibilities in order to achieve the objective of the organization. Performance can be success if the goal achieved. [1,2,3]

The development of SMEs in Indonesia has increase over years, the Indonesian government should continuing to support them by providing both capital or their entrepreneurial skills, moreover at this time SMEs in Indonesia faced the ASEAN
Economic Community (AEC) which inevitably forcing them to be ready and compete against foreign products that may enter the Indonesian market, this condition should not be underestimate by entrepreneur in this country, because if they are not prepared with this condition, their business can be defeated with the similar product that come from other country.

There are 4 factor which cause low business performance in SMEs in Indonesia, these are: 1) Almost $60 \%$ of small business still using traditional technology; 2) Low market share due to lack of capital, technology and managerial; 3) Most of SMEs are not able to meet the requirement for administrative assistance from the bank; 4) Their dependency against government facilities is too much. [4]. Then, common problem who faced SMEs in Indonesia, these are: 1) Low productivity; 2) Low added value; 3) Small investment; 4) Narrow of market; 5) Limited networking; 6) Limited access to capital resources and raw materials; 7) The management is not professional and human resources that do not have the quality to compete, these problem should always be concern for SME, because low business performance can make their business cannot operate properly. [4]

Based on condition from analysis above, the factor who affect low performance business should be improved, one of them is to increasing their entrepreneurial skills for the SMEs owner. Implementation of entrepreneurial skills improvement need concrete data belonging to the current condition if there is influence on the performance of the business. Therefore, to meet the concrete data and information require study through a research in this field.

\section{LITERATURE REVIEW}

Entrepreneur skill are abilities such as knowledge, management, and other about entrepreneurship that should be owned and known by entrepreneur that required to support his business, entrepreneur must have the competence and should always be improved due to the dynamic business conditions. $[5,6,7,8,9,10]$

Performance can be interpreted as an achievement of the work accordance with the rules and standardization that apply on the organization. Business performance refers to the level of achievement on the company in a period time. The performance of a company is a very decisive in the development of the company. The purpose of a company is: a fixed stand or survive, to earn a profit, growth, these purpose 
can be reached if the company has a good performance. $[11,12,13,14,15]$.

\section{RESEARCH METHODOLOGY}

This type of research is using verivicative method. This research was conducted to find out the entrepreneurial skills influence the performance business on SMEs owner in Narogong, Bekasi. The research period is less than one year, then the method used was cross sectional method. The independent variable in this research is entrepreneurial skill with a research problem is the dependent variable is business performance.

The entrepreneurial skill variable in this study focuses on four this things: 1) Technical skills; 2) Management skills; 3) Entrepreneurship skills; and 4) Personal maturity skills. Performance can be interpreted as an achievement of the work in accordance with the rules and standardization that apply in each of the organization. Business performance indicators include: 1) Sales growth; 2) Capital growth; 3) Addition to the workforce; 4) Market growth; 5) Marketing; and 6) Profit growth.

The population of this research include all owners of the SMEs in Narogong, Bekasi whom still active their business until 2016 which numbered 30 people. So, the sample in this research is classified into census.

\section{FINDINGS \& DISCUSSION}

Based on the correlation between entrepreneurial skills (X) on business performance (Y) is 0,617 , its interpretation of correlation coefficient 0,60 to 0,799 , that means there is strong correlation between entrepreneurial skills on business performance. P-Value in the column sig. (2-tailed) $0,000<$ 0,05 level significant $(\alpha)$, which means that entrepreneurial skills are correlated with business performance.

Based on calculation from model summary output in SPSS 23.0 known that the correlation or relationship between entrepreneurial skills with business performance obtained result 0,617 (positive). The correlation between entrepreneurial skills to business performance is strong category from interpretated coefficient correlation 0,60 to 0,799 with standar error of estimate (SEE) is 4,4410 for variable business performance. When compaired with standard deviation (STD) of business performace is 5,505, then SEE is smaller.

Based on calculation in simple linier regression on SPSS v.23, we can see the simple linear regression model that is expressed in the following equation:

$$
\begin{aligned}
& Y=a+b X \\
& Y=1,406+0,392 X
\end{aligned}
$$

Based on simple linear regression above, a content value is 1,406 , that means if there is no increase in number on entrepreneurial skills $(X=0)$, the magnitude of the business performance is 1,406. The coefficient regression on the variable entrepreneurial skills is 0,392 for one value which mean if there is increase in number on entrepreneurial skill, then business performance is also increase in number amount 0,392 for one unit and vice versa.

These are the results of the calculation from coefficient of determination from variable entrepreneur skill against business performance

$$
\begin{aligned}
& C D=r^{2} \times 100 \% \\
& =(0,617)^{2} \times 100 \% \\
& =0,380 \times 100 \% \\
& =38,06
\end{aligned}
$$

Based the result from coefficient determination for entrepreneurial skill against business performance gained $38,06 \%$. Which mean business performance has influenced $38,06 \%$ by entrepreneurial skills whereas $61,94 \%$ is influenced by other factors.

\section{CONCLUSION}

The results of this research that has been done by using verivicative analysis by using simple linear regression technique can be take the following conclusion: The variable of entrepreneurial skill has a direct simultaneous influence on business performance with strong relationship from the variables to influence the owners of SMEs in improving their business performance. That shows the better entrepreneurial skills possessed by the owner of SMEs the better business performance was also created by their companies.

\section{REFERENCES}

[1] Taylor J, Armstrong HW. Regional Economics and Policy. Amazon. Com; 2000.

[2] Handriani, E. Pengaruh Faktor Internal Eksternal, Entrepreneurial Skill ,Strategi Dan Kinerja Terhadap Daya Saing Ukm, Di Kabupaten Semarang. Dinamika Sosial Ekonomi; 2011. 7(1). 47-69.

[3] Sudarmanto. Kinerja dan Pengembangan Kompetensi SDM. Yogyakarta: Pustaka Pelajar; 2014

[4] Ardiana, I.D.K.R., Brahmayanti, I.A., \& Subaedi.. Kompetensi SDM UKM dan Pengaruhnya Terhadap Kinerja UKM di Surabaya, Jurnal Manajemen dan Kewirausahaan;2010. 12(1), 42-55.

[5] Hisrich R. Peters. Michael P. Shepherd D. Entrepreneurship, 7th ed. Bouston: Mc Graw-Hill; 2008

[6] Baum JR, Locke EA. The relationship of entrepreneurial traits, skill, and motivation to subsequent venture growth. Journal of applied psychology. 2004 Aug;89(4):587.

[7] Rachma, F, Hermiati, T. Entrepreneurial Skills and Characteristics Analysison the Graduates of the Department of Administrative Sciences, FISIP Universitas Indonesia. Journal of Administrative Sciences \& Organization. 2010. 17(3), 262-275.

[8] Riyanti, B.P.D. Kewirausahaan dari Sudut Pandang Psikologi Kepribadian. Jakarta: Penerbit Gramedia Widiasarana Indonesia; 2003

[9] Shook CL, Priem RL, McGee JE. Venture creation and the enterprising individual: A review and synthesis. Journal of Management. 2003 Jun 1;29(3):379-99.

[10] Watson, H. dkk. Entrepreneurial Skills. Cape Town: Juta; 2008

[11] Chakravarthy BS. Measuring strategic performance. Strategic management journal. 1986 Sep 1;7(5):437-58. 
[12] Gitman, J. L. Principle Managerial Finance. Seventh Edition. New York: Harper Collins College Publishers; 1994

[13] Mwita, I. J. Performance Management Model. The International Journal of Public Sector Management, MCB University Press, 13(1); 2003
[14] Rahayu, P.S. Peningkatan Kinerja Melalui Orientasi Kewirausahaan, Kemampuan Manajemen, dan Strategi Bisnis. Jurnal Manajemen dan Kewirausahaan; 2009. Vol.11, No. 1, 46-58.

[15] Suhardi, T. Entrepreneurship (Kewirausahaan) Menumbuh kembangkan Usaha Mikro dan Kecil. Unpad Press; 2009 